\title{
Interaction of Aqueous Extract of Pleurotus pulmonarius (Fr.) Quel-Champ. with Glyburide in Alloxan Induced Diabetic Mice
}

\author{
Sachin L. Badole, Naimesh M. Patel, Prasad A. Thakurdesai and Subhash L. Bodhankar \\ Pharmacology Division, Poona College of Pharmacy, Bharati Vidyapeeth Deemed University, Erandwane, \\ Paud Road, Pune 411-038, India
}

\begin{abstract}
Mushrooms are low calorie food with very little fat and are highly suitable for obese persons. With no starch and very low sugars, they are the 'delight of the diabetics'. Combination of herbal drugs (or isolated phytochemicals) is found to be beneficial in certain diseases when given along with conventional drugs. The aim of the present study was to evaluate the effects of aqueous extract of Pleurotus pulmonarius (Lentinaceae) (called as PP-aqu) and its interaction with glyburide in alloxan induced diabetic mice. The diabetic mice treated were with PP-aqu $(500 \mathrm{mg} / \mathrm{kg}$, p.o.) alone or combination with glyburide $(10 \mathrm{mg} / \mathrm{kg}$, p.o.) for 28 days. Blood samples were collected by orbital sinus puncture using heparinized capillary glass tubes and were analyzed for serum glucose on 0,7 th, 14th, 21st and 28th days. Body weights and mortality were noted during the study period. In oral glucose tolerance test (OGTT), glucose $(2.5 \mathrm{~g} / \mathrm{kg}$, p.o.) was administered with either vehicle, PP-aqu alone or in combination with glyburide and serum glucose level analyzed at 0,30,60 and 120 min after drug administration. Administration of PP-aqu $(500 \mathrm{mg} / \mathrm{kg})$ and its combination with glyburide $(10 \mathrm{mg} / \mathrm{kg})$ significantly $(P<0.001)$ decreased serum glucose level in diabetic mice. In OGTT, glyburide or PP-aqu treatment alone or their combination produced significant $(P<0.001)$ increase in glucose threshold. Thus we suggest that $P$. pulmonarius showed potent and synergistic antihyperglycemic effect in combination with glyburide.
\end{abstract}

Keywords: Pleurotus pulmonarius-glyburide-serum glucose-oral glucose tolerance test (OGTT)

\section{Introduction}

Mushrooms are a group of fleshy macroscopic fungi, which until recently, as other fungi, were induced in the plant kingdom because of cell wall and spores. Mushroom have been valued throughout the world as both food and medicine for thousands of years (1-3). There are many varieties of mushrooms, species of which Pleurotus are characterized by a white spore print, attached to gills, often with an eccentric stip,

For reprints and all correspondence: Dr S. L. Bodhankar, Professor and Head, Department of Pharmacology, Bharati Vidyapeeth Deemed

University, Poona College of Pharmacy, Erandwane, Pune 411-038,

India. Tel: +91-20-24537237 (Ext. 29); Fax: +91-20-25439386;

E-mail: sbodh@yahoo.com or no stip at all. They are commonly known as 'oyster mushrooms' (4).

Mushrooms are highly nutritive as they contain good quality proteins, vitamins and minerals $(5,6)$. Mushrooms are low calorie food with very little fat and are highly suitable for obese persons. With no starch and very low sugars, they are the 'delight of the diabetics' (7). In adequate quantities and low in sugars they can serve as medicinal foods for diabetes. Earlier studies have reported insulin release and insulin like activity of other mushroom species like Agaricus campestris (8-10). However, there is paucity of reports on the antihyperglycemic activity of Pleurotus.

The increasing use of herbal medicinal products in the community where people are also receiving prescription 
medicines suggests that adverse herb-drug interactions may be of significant public health consequence (11). Geriatric patients often add herbal medicines to medications prescribed by their physicians, yet do not always inform the physician (12). Whereas most herbal remedies, when used as directed and under the supervision of knowledgeable individuals, are safe, the potential for adverse effects or intoxications certainly exists. In addition, because nearly all herbal remedies contain multiple, biologically active constituents, interaction with conventional drugs is a concern (13-15). Hence, the likelihood of herb-drug interactions is theoretically higher than drug-drug interactions (16). On the other hand, combination of herbal drugs (or isolated phytochemicals) are found to be beneficial in certain diseases (17-19) when given along with conventional drugs. Herbal agents when given in combination with prescription medication may favorably alter pharmacokinetic (20) as well as pharmacodynamic $(19,21,22)$ of prescription medications. However, to date there is less evidence relating to herb-drug interaction in case of antidiabetic medicines and understanding of the involved mechanisms is also far from complete (16).

Recently, we have reported the hypoglycemic effects of aqueous extract of Pleurotus pulmonarius (Fr.) Quel.-Champ in alloxan-induced diabetic mice and increased oral glucose tolerance in diabetic (OGTT model) mice at dose levels $\geq 250 \mathrm{mg} / \mathrm{kg}$, p.o. (23). In this article we are reporting interaction of aqueous extract of $P$. pulmonarius with glyburide on serum glucose levels and oral glucose tolerance test (OGTT) in alloxan-induced diabetic mice.

\section{Methods}

\section{Drugs and Chemicals}

The mushroom of $P$. pulmonarius (Fr.) Quel.-Champ (Lentinaceae) was provided to us as a gift sample from Bajaj Orchard, Pvt. Ltd, Mumbai, India. It was authenticated by Dr A. M. Mujumdar, Department of Botany, at Agharkar Research Institute, Pune and voucher specimen was deposited at that Institute. Glyburide (Ranbaxy Pharma. Ltd, India), alloxan monohydrate (Spectrochem, India), glucose estimation kit (Accurex Biomedical Pvt. Ltd, India) and d-glucose (S.D. Fine-Chem. Ltd, India) were purchased from respective companies.

\section{Experimental Animals}

Swiss albino male mice $(25-30 \mathrm{~g})$ were purchased from National Toxicology Centre, Pune, India. They were maintained at a temperature of $25 \pm 1{ }^{\circ} \mathrm{C}$ and relative humidity of $45-55 \%$ under 12 -h light:12-h dark cycle.
The animals had free access to food pellets (Chakan Oil Mills, Pune, India) and water ad libitum. The experimental protocol was approved by the Institutional Animal Ethics Committee (IAEC) of Poona College of Pharmacy, Pune, India.

\section{Preparation of Aqueous Extract of $P$. pulmonarius (PP-aqu)}

Weighed quantity powder of air-dried $P$. pulmonarius was added to distilled water $(1: 15)$, boiled for $20 \mathrm{~min}$ on water bath, cooled to room temperature and filtered. The filtrate was dried on tray dryer at $70^{\circ} \mathrm{C}$ (yield $24 \% \mathrm{w} / \mathrm{w}$ ). The dry extract powder was dissolved in distilled water to prepare drug solution at a concentration of $100 \mathrm{mg} / \mathrm{ml}$ and used for pharmacological studies.

\section{Induction of Experimental Diabetes}

Diabetes was induced in mice by a single intravenous injection of aqueous alloxan monohydrate $(70 \mathrm{mg} / \mathrm{kg}$, i.v. $)$ (24). After $48 \mathrm{~h}$, the animals showing serum glucose level above $200 \mathrm{mg} / \mathrm{dl}$ (diabetic) were selected for the study. All mice were allowed free access to tap water and pellet diet.

\section{Collection of Blood and Determination of Serum Glucose}

Blood samples from the control and experimental mice were collected by orbital sinus puncture using heparinized capillary glass tubes. The blood samples so collected were analyzed for glucose levels by glucose oxidase peroxidase (GOD/POD) method as described earlier (25) and serum glucose levels were expressed in $\mathrm{mg} / \mathrm{dl}$.

\section{Alloxan Treated Diabetic Mice Model}

The diabetic mice were divided into four groups of six animals each. The mice were administered orally with either vehicle (distilled water, $10 \mathrm{ml} / \mathrm{kg}$ ), PP-aqu $(500 \mathrm{mg} / \mathrm{kg})$, glyburide $(10 \mathrm{mg} / \mathrm{kg})$ and the combination of PP-aqu $(500 \mathrm{mg} / \mathrm{kg})$ with glyburide $(10 \mathrm{mg} / \mathrm{kg})$.

Acute study involved estimation of serum glucose at 0 , 2, 4, 6 and $24 \mathrm{~h}$ after drug administration. Subacute study involved repeated administration of drug for 28 days at prefixed time and serum glucose level was estimated on 7th, 14th, 21st and 28th day. Mean change in serum glucose level and standard error mean (SEM) were calculated. The mice were weighed daily during the study period of 28 days and their body weights were noted. From this data, mean change in body weight and SEM were calculated. The mortality of mice was also noted during the study period and percentage mortality was calculated. 


\section{Oral Glucose Tolerance Test in Alloxan Treated Diabetic Mice}

Diabetic mice were divided into four groups of six animals each. The animals were fasted overnight before commencing the experiment.They were adminstred orally with either vehicle (distilled water, $10 \mathrm{ml} / \mathrm{kg}$ ), PP-aqu $(500 \mathrm{mg} / \mathrm{kg})$, glyburide $(10 \mathrm{mg} / \mathrm{kg})$ and the combination of PP-aqu $(500 \mathrm{mg} / \mathrm{kg})$ with glyburide $(10 \mathrm{mg} / \mathrm{kg})$. The mice of all the groups were loaded with d-glucose $(2.5 \mathrm{gm} / \mathrm{kg})$ solution after half an hour of drug administration. Serum glucose levels were estimated $30 \mathrm{~min}$ prior to glucose administration and at 0,30,60 and 120 min after glucose loading.

\section{Statistical Analysis}

The results are expressed as mean \pm SEM. Comparison between the groups was made by two-way analysis of variance (ANOVA) followed by post hoc Dunnett's test.

\section{Results}

\section{Antihyperglycemic Influence on Serum Glucose Level} in Alloxan-induced Diabetes

Figure 1 showed antihyperglycemic effects of various treatments against alloxan-induced diabetic mice. Acute administration of PP-aqu $(500 \mathrm{mg} / \mathrm{kg})$ showed peak decrease in serum glucose levels in alloxan-induced diabetic mice at $2 \mathrm{~h}(P<0.001)$. However, effects gradually reduced at $4 \mathrm{~h}(P<0.01)$ and $6 \mathrm{~h}(P<0.01)$. Glyburide $(10 \mathrm{mg} / \mathrm{kg})$ showed potent and significant effect $(P<0.001)$ at all time points tested. However, combination of PP-aqu $(500 \mathrm{mg} / \mathrm{kg})$ and glyburide $(10 \mathrm{mg} / \mathrm{kg})$

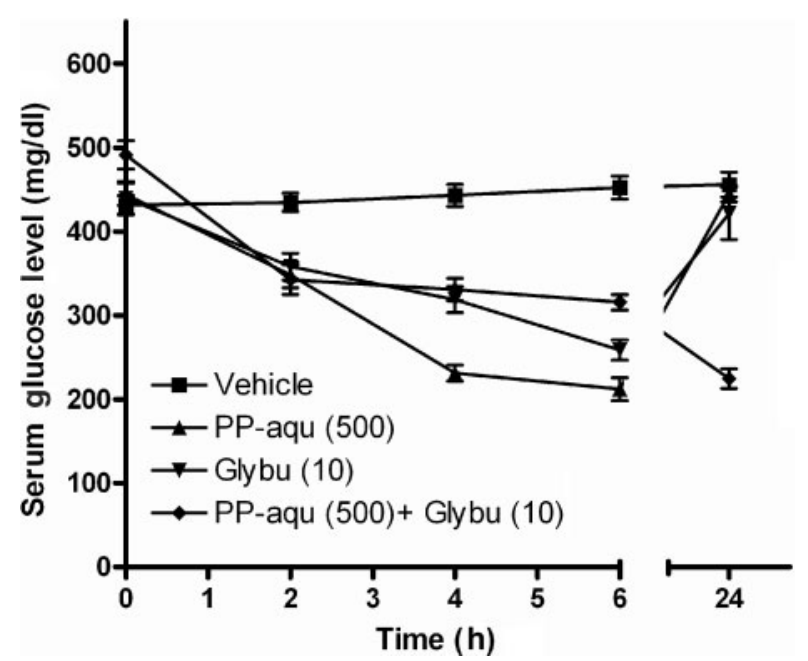

Figure 1. Effect of acute pretreatment of aqueous extract of $P$. pulmonarius and glyburide on serum glucose level in alloxan-induced diabetes in mice. demonstrated sharp decrease $(P<0.001)$ in serum glucose levels at all the time points tested (Fig. 1).

\section{Sub-acute Antihyperglycemia on Serum Glucose Levels in Alloxan Induced Diabetes}

Glyburide $(10 \mathrm{mg} / \mathrm{kg}), \quad$ PP-aqu $(500 \mathrm{mg} / \mathrm{kg})$ or their combinations showed significant $(P<0.001)$ antihyperglycemic effect after 7th, 14th, 21st and 28th day of treatments. The effects of combinations were more pronounced than single drug treatment (Fig. 2).

\section{Reversal of Loss of Body Weight and Mortality Rate in Alloxan Induced Diabetes}

Administration of vehicle (distilled water, $10 \mathrm{ml} / \mathrm{kg}$, p.o.) in alloxan induced diabetic mice resulted in gradual decease $(P<0.001)$ in body weight during the period of 28 days (Fig. 3). All the treatments (PP-aqu or glyburide or their combinations) could reverse alloxan-induced weight loss in mice after 7th, 14th, 21st and 28th day of treatments (Fig. 3). Administration of PP-aqu alone caused $14 \%$ mortality in alloxan induced diabetic mice during 28 days study period (Data not tabulated). On single drug treatment of glyburide $(10 \mathrm{mg} / \mathrm{kg})$ caused $25 \%$ mortality, whereas combination of PP-aqu with glyburide $(10 \mathrm{mg} / \mathrm{kg})$ caused $25 \%$ mortality in mice.

\section{Increased Glucose Threshold in OGTT by Treatments}

In the OGTT, administration of glucose load $(2.5 \mathrm{~g} / \mathrm{kg})$ increased serum glucose levels significantly $(P<0.001)$ after $30 \mathrm{~min}$ of glucose loading in alloxan treated diabetic mice (Fig. 4). Glyburide $(10 \mathrm{mg} / \mathrm{kg})$ or PP-aqu treatment alone or in combination produced significant $(P<0.001)$ increase in glucose threshold within $30 \mathrm{~min}$ of glucose

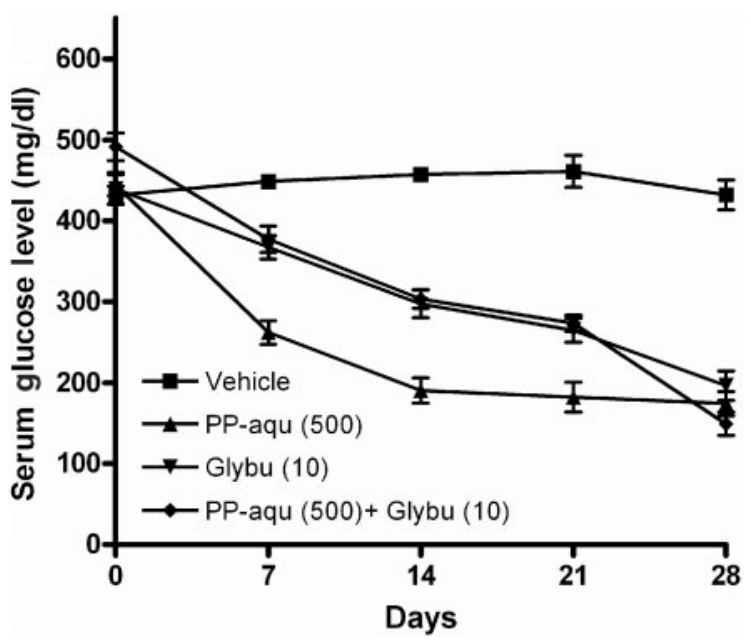

Figure 2. Effect of subacute pretreatment of aqueous extract of $P$. pulmonarius and glyburide on serum glucose level in alloxan induced diabetes in mice. 
loading and the effects persisted till $120 \mathrm{~min}$ (Fig. 4 and Table 1).

\section{Discussion}

In the past, many mushroom varieties have been reported to possess hypoglycemic activities in animals $(8,10)$ as

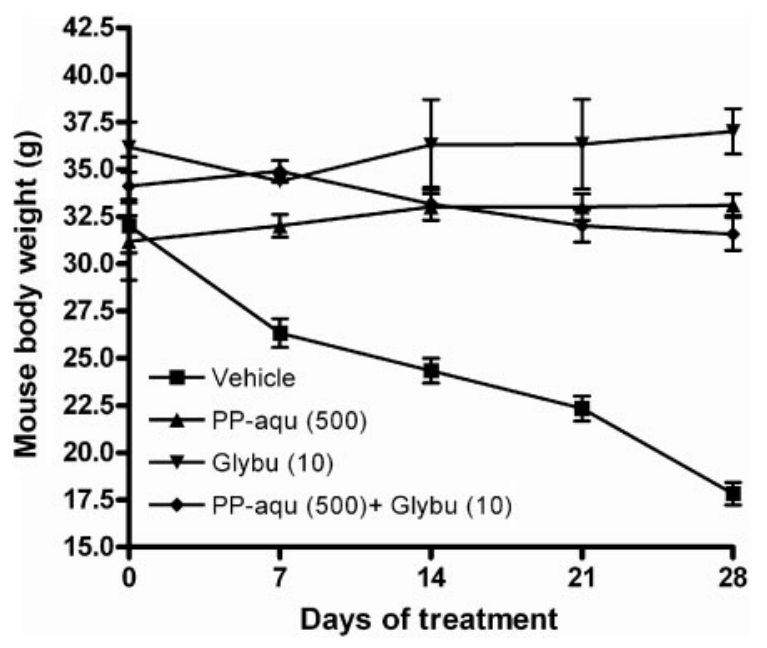

Figure 3. Effect of sub-acute pretreatment of aqueous extract of $P$. pulmonarius and glyburide on body weights of alloxan induced diabetes in mice.

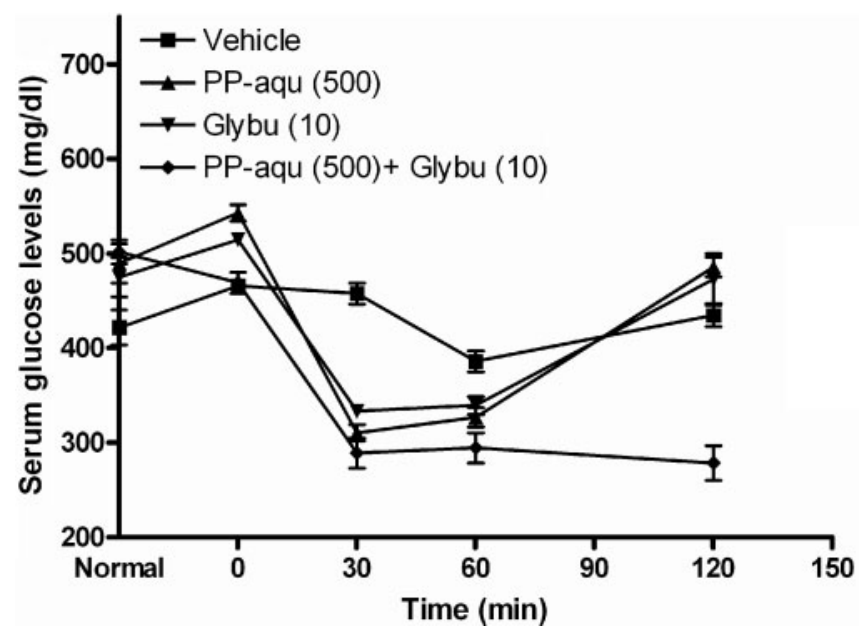

Figure 4. Effect of acute pretreatment of aqueous extract of $P$. pulmonarius and glyburide on serum glucose level in OGTT in mice. well as in diabetic patients (26). Studies in normal and streptozotocin diabetic mice treated with mushroom variety, Agaricus bisporus, retards the development of hyperglycemia, hyperphagia, polydipsia, body weight loss and glycated hemoglobin in streptozotocin treated mice (10) by counteracting reduction in plasma and pancreatic insulin concentration and by improving hypoglycemic effect of exogenous insulin.

The antihyperglycemic effect of PP-aqu was limited to $6 \mathrm{~h}$ (with peak effect at second $\mathrm{h}$ ) when administered alone. But combination of PP-aqu and gliburide showed sustained anti-hyperglycemic effect at $24 \mathrm{~h}$ (Fig. 1) suggesting the advantage of combination in long-term treatment. The more pronounced effect of the extract in alloxan-induced diabetic mice may possibly be due to limited or compromised action of insulin in diabetic condition, and conversely a greater and more direct role of the antihyperglycemic principle present in the extract. Several antihyperglycemic principles from plant origin have been reported to have antihyperglycemic effects upto $24 \mathrm{~h}$ (27-29). On the other hand, combination of PP-aqu with glyburide showed its peak effect at $24 \mathrm{~h}$. It thus seems possible that more than one phytochemical from PP-aqu showed antihyperglycemic effect.

Moreover, PP-aqu alone or in combination with glyburide also protected the weight loss induced by alloxan in the present study (Fig. 3) and this result is supported by earlier studies from few other plant extracts (10) and so substantiates the usefulness of combination in long-term treatment of diabetes.

In OGTT, the doses of PP-aqu $(500 \mathrm{mg} / \mathrm{kg}$, p.o.) increased the tolerance for glucose (Fig. 4) suggesting increased peripheral utilization of glucose in both diabetic as well as nondiabetic (normal) mice.

Antihyperglycemic effects observed in alloxan induced mice and in OGTT can be attributed to several mechanisms. Many varieties of mushrooms have been reported to possess antihyperglycemic activity through various mechanism like glucose/insulin metabolism and/or by enhancing peripheral insulin sensitivity $(9,30)$ or by enhancing insulin release by Islets of Langerhans $(8,31)$. Insulin-releasing and insulin-like activity in $A$. campestris (a variety of mushroom) is reported earlier (8).

Table 1. Effect of treatments on increased glucose threshold in OGTT

\begin{tabular}{|c|c|c|c|c|c|}
\hline \multirow[t]{2}{*}{ Treatment (dose in $\mathrm{mg} / \mathrm{kg}$, p.o.) } & \multicolumn{5}{|c|}{ Mean serum gluose level (mg/dl) } \\
\hline & -30 & $\mathrm{O} \min$ & $30 \mathrm{~min}$ & $60 \mathrm{~min}$ & $120 \mathrm{~min}$ \\
\hline Vehicle & $421.53 \pm 18.59$ & $465.76 \pm 4.54$ & $457.46 \pm 11.22$ & $385.90 \pm 11.02$ & $434.62 \pm 12.16$ \\
\hline Glybu (10) & $474.80 \pm 20.85$ & $514.38 \pm 6.47$ & $333.05 \pm 5.13 * * *$ & $339.13 \pm 9.56^{* * *}$ & $472.68 \pm 7.28$ \\
\hline PP-aqu $(500)+$ Glybu (10) & $501.44 \pm 12.78$ & $468.95 \pm 1.25$ & $288.81 \pm 15.90^{* * *}$ & $294.37 \pm 15.81^{* * *}$ & $278.35 \pm 18.22 * * *$ \\
\hline
\end{tabular}

$N=6$, PP-aqu- of aqueous extract of $P$. pulmonarius; Glybu-Glyburide. All the groups were administrated with glucose $10 \mathrm{ad}(2.5 \mathrm{~g} / \mathrm{kg})$ at $0 \mathrm{~min}$. $* P<0.05, * * * P<0.001$. 
Lectins from $A$. bisporus and A. campestris stimulate insulin and glucagon release from isolated rat islets in the presence of glucose and specific interaction between mushroom lectin and its receptors (leading to conformational changes in the structure of the membranes of the islet $\alpha_{2^{-}}$and $\beta$-cells) that facilitate exocytosis is also proposed earlier (31). Effects of water-soluble extract of maitake mushroom have been reported to have antihyperglycemic activity by lowering of circulating glucose and insulin concentrations and suggested to work primarily by enhancing peripheral insulin sensitivity (32). Therefore, $P$. pulmonarius mediated decrease in serum glucose level in diabetic mice may mediated by one of these mechanisms.

Guanide, a known hypoglycemic substance related to biguanide class of oral antidiabetic drugs, has been detected in edible mushroom of Pleurotus species (33) and might be responsible for the antidiabetic effect. This phytochemical may be responsible for synergistic action of PP-aqu with glyburide against alloxan-induced diabetic mice as well as OGTT that is observed in our study. It is generally agreed that glyburide binds to insulin receptors on beta cells. Following this binding, closure of ATP-dependent potassium channels leads to opening of voltage-gated $\mathrm{Ca}^{2+}$ channels, an increased $\mathrm{Ca} 2+$ influx and the subsequent stimulation of insulin containing granules' exocytosis. (34-37) and reduces fasting plasma glucose concentration.

Mushrooms contain a variety of secondary metabolites, including various phenolic compounds, which have been may act as excellent anti-oxidants (38-42). Oxidative stress, defined as an imbalance between the production of reactive oxygen species (ROS) and anti-oxidant defense, is considered to be an important pathogenic factor in diabetes mellitus and its complications (43). It has been postulated that enhanced generation of ROS may take part in the pathogenesis of diabetic microvascular complication - retinopathy (44). The relationship of anti-oxidant potential of herbs and their antidiabetic activity have been shown many times in the past (45-50). Niacin-bound chromium constituent from Maitake mushroom $(9,51)$ and nicotinamide $(52)$ is reported to ameliorate diabetes mellitus in laboratory animals as well as in clinics. Therefore, anti-oxidant components in PP-aqu (niacin and ascorbic acid that are present in remarkable proportion) might play important contributory factor in the antihyperglycemic effect of $P$. pulmonarius.

Preliminary phytochemical analysis of $P$. pulmonarius showed the presence of proteins, minerals, vitamins and carbohydrates (Data not tabulated). Such constituents are confirmed also by Food and Agriculture Organization of United Nations (53). Mushrooms consist of $\sim 20-35 \%$ proteins. The glycoproteins constituents have been shown to have antihypergycemic effect (54).

\section{Conclusions}

It was thus apparent from the results that PP-aqu $(500 \mathrm{mg} / \mathrm{kg})$ showed significant antihyperglycemic effect in alloxan induced diabetic mice. It not only halts progression of diabetes (as it reduced weight loss) but also reduced the mortality of alloxan induced diabetic mice by $\sim 50 \%$. PP-aqu $(500 \mathrm{mg} / \mathrm{kg})$ in combination with glyburide $(10 \mathrm{mg} / \mathrm{kg})$ showed potent synergistic antihyperglycemic effects probably due to increased insulin secretion. The results from OGTT also supports the possibility of effective combination therapy of $P$. pulmonarius with glyburide as an effective anti-diabetic therapy. The marked and prolonged activity necessitates a more comprehensive chemical and pharmacological investigation to elucidate the exact mechanism and to isolate and identify it's active principle(s).

\section{Acknowledgements}

The authors acknowledge Dr S. S. Kadam, Principal and Dr K. R. Mahadik Vice-Principal, Poona College of Pharmacy, Bharati Vidyapeeth Deemed University, Pune for providing necessary facilities to carry out the study. We are also thankful to Bajaj Orchard, a division of Trinity Bio-Tech, Mumbai, India, for sending us a gift sample of $P$. Pulmonarius.

\section{References}

1. Lindequist U, Niedermeyer TH, Julich WD. The pharmacological potential of mushrooms. Evid Based Complement Alternat Med 2005;2:285-99.

2. Wright T. Medicinal mushrooms. Nutraceuticals World. Ramsey, NJ: Roman Publishing, 2004, 26-9.

3. Tribe I, Tosco U. The World of Mushrooms. Vol viii. London: Orbis Publishing, 1973.

4. Miles PG, Chang S-T. Mushroom Biology: Concise Basics and Current Development. New York: World Scientific Publishing Company, 1997.

5. Khanna P, Garcha HS. Pleurotus mushroom- A source of food protein. Mushroom News Lett Tropics 1984;4:9-14.

6. Flegg PB, Maw GA. Mushroom and their possible contribution to world protein needs. Mushroom J 1976;48:396-405.

7. Bano Z. The nutritive value of mushrooms. Paper presented at: First Symposium on survey and cultivation of edible mushrooms of India, Regional Research Laboratory, Jammu, 1976; pp. 148-69.

8. Gray AM, Flatt PR. Insulin-releasing and insulin-like activity of Agaricus campestris (mushroom). J Endocrinol 1998;157:259-66.

9. Talpur N, Echard B, Dadgar A, Aggarwal S, Zhuang C, Bagchi D, et al. Effects of Maitake mushroom fractions on blood pressure of Zucker fatty rats. Res Commun Mol Pathol Pharmacol 2002; 112:68-82.

10. Swanston-Flatt SK, Day C, Flatt PR, Gould BJ, Bailey CJ. Glycaemic effects of traditional European plant treatments for diabetes. Studies in normal and streptozotocin diabetic mice. Diabetes Res. 1989;10:69-73.

11. Coxeter PD, McLachlan AJ, Duke CC, Roufogalis BD. Herb-drug interactions: an evidence based approach. Curr Med Chem 2004;11:1513-25.

12. Bressler R. Herb-drug interactions: interactions between kava and prescription medications. Geriatrics 2005;60:24-25.

13. Poppenga RH. Herbal medicine: potential for intoxication and interactions with conventional drugs. Clin Tech Small Anim Pract 2002;17:6-18. 
14. Fugh-Berman A, Ernst E. Herb-drug interactions: review and assessment of report reliability. Br J Clin Pharmacol 2001;52: 587-95.

15. Woodward KN. The potential impact of the use of homeopathic and herbal remedies on monitoring the safety of prescription products. Hum Exp Toxicol 2005;24:219-33.

16. Izzo AA. Herb-drug interactions: an overview of the clinical evidence. Fundam Clin Pharmacol 2005;19:1-16.

17. Samane S, Noel J, Charrouf Z, Amarouch H, Haddad PS. Insulin-sensitizing and anti-proliferative effects of Argania spinosa seed extracts. Evid Based Complement Alternat Med 2006;3:317-27.

18. Zeng C, Liu Y, Wang Z, He D, Huang L, Yu P, et al. Activation of D3 dopamine receptor decreases angiotensin II type 1 receptor expression in rat renal proximal tubule cells. Circ Res 2006;99: 494-500.

19. Kelly KM. Complementary and alternative medical therapies for children with cancer. Eur J Cancer 2004;40:2041-6.

20. Singh M, Varshneya C, Telang RS, Srivastava AK. Alteration of pharmacokinetics of oxytetracycline following oral administration of Piper longum in hens. J Vet Sci 2005;6:197-200.

21. Lin YC, Bioteau AB, Ferrari LR, Berde CB. The use of herbs and complementary and alternative medicine in pediatric preoperative patients. J Clin Anesth 2004;16:4-6.

22. Awang DV, Fugh-Berman A. Herbal interactions with cardiovascular drugs. J Cardiovase Nurs 2002;16:64-70.

23. Badole SL, Shah SN, Patel NN, Thakurdesai PA, Bodhankar SL. Hypoglycemic activity of aqueous extract of Pleurotus pulmonarius (Fr.) Quel.-Champ in alloxan induced diabetic mice. Pharm Biol 2006;44:421-5.

24. Rao BK, Kesavulu MM, Giri R, Appa Rao C. Antidiabetic and hypolipidemic effects of Momordica cymbalaria Hook. fruit powder in alloxan-diabetic rats. J Ethnopharmacol 1999;67:103-9.

25. Abdel-Barry JA, Abdel-Hassan IA, Al-Hakiem MH. Hypoglycaemic and antihyperglycaemic effects of Trigonella foenum- graecum leaf in normal and alloxan induced diabetic rats. J Ethnopharmacol 1997;58:149-55.

26. Konno S, Tortorelis DG, Fullerton SA, Samadi AA, Hettiarachchi J, Tazaki H. A possible hypoglycaemic effect of maitake mushroom on type 2 diabetic patients. Diabet Med 2001;18:1010.

27. Hikino H, Takahashi M, Konno C, Ishimori A, Kawamura T, Namiki T. Effect of glycans of Saccharum officinarum on carbohydrate and lipid metabolism of rats. $J$ Ethnopharmacol $1985 ; 14: 261-8$.

28. Akhtar MS, Khan QM, Khaliq T. Effects of Portulaca oleracae (Kulfa) and Taraxacum officinale (Dhudhal) in normoglycaemic and alloxan-treated hyperglycaemic rabbits. J Pak Med Assoc 1985;35:207-10.

29. Takahasi M, Konno C, Hikino H. Isolation and hypoglycemic activity of Anemorans A, B, C and D, glycans of Anemarrhema asphodelcides rhizomes. Planta Med 1985;51:100-2.

30. Talpur NA, Echard BW, Fan AY, Jaffari O, Bagchi D, Preuss HG. Antihypertensive and metabolic effects of whole Maitake mushroom powder and its fractions in two rat strains. Mol Cell Biochem 2002;237:129-36.

31. Ewart RB, Kornfeld S, Kipnis DM. Effect of lectins on hormone release from isolated rat islets of langerhans. Diabetes. 1975;24: 705-14.

32. Manohar V, Talpur NA, Echard BW, Lieberman S, Preuss HG. Effects of a water-soluble extract of maitake mushroom on circulating glucose/insulin concentrations in KK mice. Diabetes Obes Metab 2002;4:43-8.

33. Windholz M. The Merck index: an encyclopedia of chemicals, drugs and biologicals, 10th edn. New Jersey: Merck \& Co., 1983.

34. Boyd AE. Sulfonylurea receptors, ion channels, and fruit flies. Diabetes 1988;37:847-50.
35. Groop LC. Sulfonylureas in NIDDM. Diabetes Care 1992;15: $737-54$.

36. Patane G, Piro S, Anello M, Rabuazzo AM, Vigneri R, Purrello F. Exposure to glibenclamide increases rat beta cells sensitivity to glucose. Br J Pharmacol 2000;129:887-92.

37. Elmi A, Idahl LA, Sehlin J. Relationships between the $\mathrm{Na}(+) / \mathrm{K}(+)$ pump and ATP and ADP content in mouse pancreatic islets: effects of meglitinide and glibenclamide. Br J Pharmacol 2000; 131:1700-06.

38. Ishikawa Y, Morimoto K, Hamasaki T. Flavoglaucin, a metabolite of Eurotium Chevalieri, its antioxidation and synergism with tocopherol. J Am Oil Chem Soc 1984;61:1864-8.

39. Mau JL, Lin HC, Song SF. Antioxidant properties of several specialty mushrooms. Food Res Int 2002;35:519-26.

40. Cheung PC, Lee MY. Fractionation and characterization of mushroom dietary fiber (nonstarch polysaccharides) as potential nutraceuticals from sclerotia of Pleurotus tuber-regium (Fries) singer. J Agric Food Chem 2000;48:3148-51.

41. Fu H, Shieh DE. Antioxidant and free radical scavenging activities of edible mushrooms. J Food Lipids 2002;9:35-46.

42. Yang JH, Lin HC, Mau JL. Antioxidant properties of several commercial mushrooms. Food Chem 2002;77:229-35.

43. Gumieniczek A, Hopkala H, Rolinski J, Bojarska-Junak A. Antioxidative and anti-inflammatory effects of repaglinide in plasma of diabetic animals. Pharmacol Res 2005;52:162-6.

44. Siemianowicz K, Gminski J, Telega A, Wojcik A, Posielezna B, Grabowska-Bochenek R, et al. Blood antioxidant parameters in patients with diabetic retinopathy. Int J Mol Med 2004;14:433-7.

45. Reddy SV, Tiwari AK, Kumar US, Rao RJ, Rao JM. Free radical scavenging, enzyme inhibitory constituents from antidiabetic Ayurvedic medicinal plant Hydnocarpus wightiana Blume. Phytother Res 2005;19:277-81.

46. Satheesh MA, Pari L. Antioxidant effect of Boerhavia diffusa L. in tissues of alloxan induced diabetic rats. Indian $J$ Exp Biol 2004;42:989-92.

47. Sabu MC, Kuttan R. Antidiabetic activity of Aegle marmelos and its relationship with its antioxidant properties. Indian $J$ Physiol Pharmacol 2004;48:81-8.

48. Ramkumar KM, Latha M, Venkateswaran S, Pari L, Ananthan R, Bai VN. Modulatory effect of Gymnema montanum leaf extract on brain antioxidant status and lipid peroxidation in diabetic rats. J Food Med 2004;7:366-71.

49. Vedavanam K, Srijayanta S, O'Reilly J, Raman A, Wiseman H. Antioxidant action and potential antidiabetic properties of an isoflavonoid-containing soyabean phytochemical extract (SPE). Phytother Res 1999;13:601-8.

50. Kumari K, Augusti KT. Antidiabetic and antioxidant effects of S-methyl cysteine sulfoxide isolated from onions (Allium cepa Linn) as compared to standard drugs in alloxan diabetic rats. Indian J Exp Biol 2002;40:1005-9.

51. Talpur N, Echard BW, Yasmin T, Bagchi D, Preuss HG. Effects of niacin-bound chromium, Maitake mushroom fraction SX and (-)-hydroxycitric acid on the metabolic syndrome in aged diabetic Zucker fatty rats. Mol Cell Biochem 2003;252:369-77.

52. Pan J, Chan EK, Cheta D, Schranz V, Charles MA. The effects of nicotinamide and glimepiride on diabetes prevention in BB rats. Life Sci 1995;57:1525-32.

53. Food and Agriculture Organization of the United Nations. Food Composition Table for Use in Africa. Vol ix. Bethesda, MD: US Department of Health, Education, and Welfare, Nutrition Program, and Food Consumption and Planning Branch, Food and Agriculture Organization of the United Nations, 1968.

54. Kusano S, Abe H, Tamura H. Isolation of antidiabetic components from white-skinned sweet potato (Ipomoea batatas L.). Biosci Biotechnol Biochem 2001;65:109-14.

Received January 10, 2006; accepted January 16, 2007 


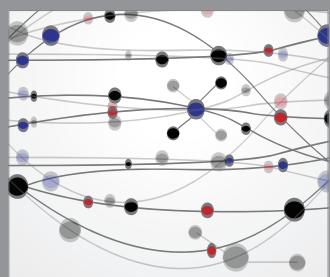

The Scientific World Journal
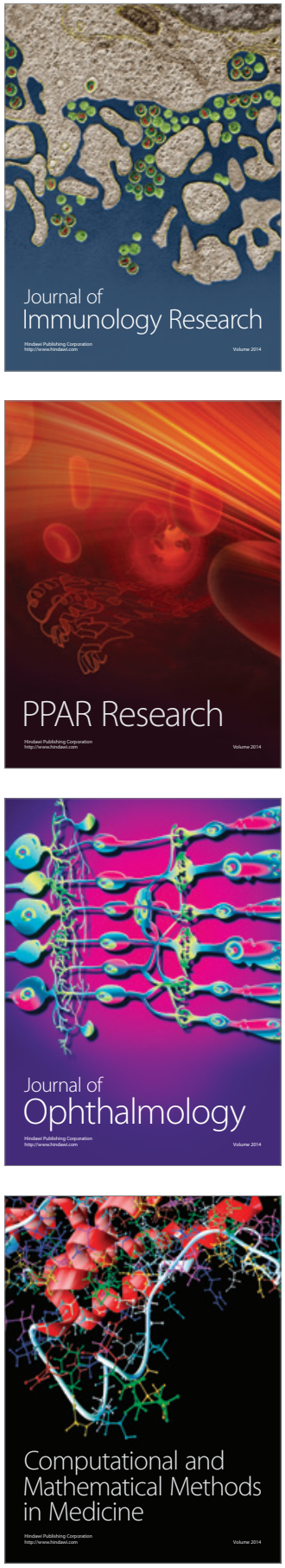

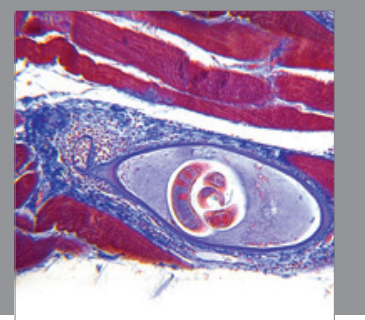

Gastroenterology

Research and Practice
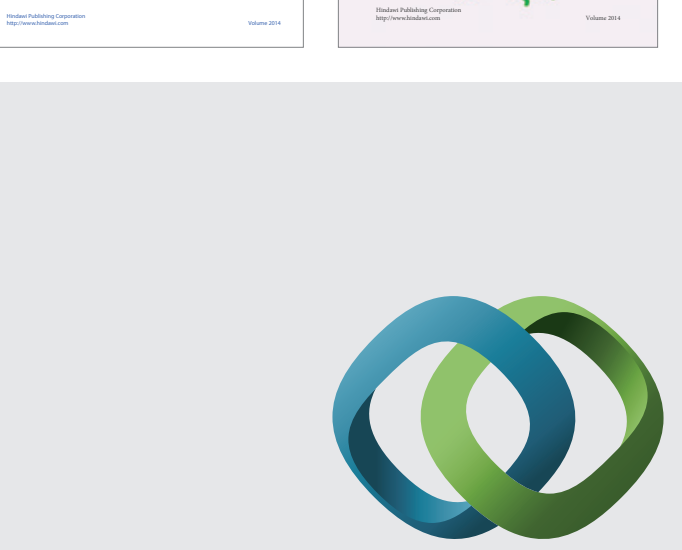

\section{Hindawi}

Submit your manuscripts at

http://www.hindawi.com
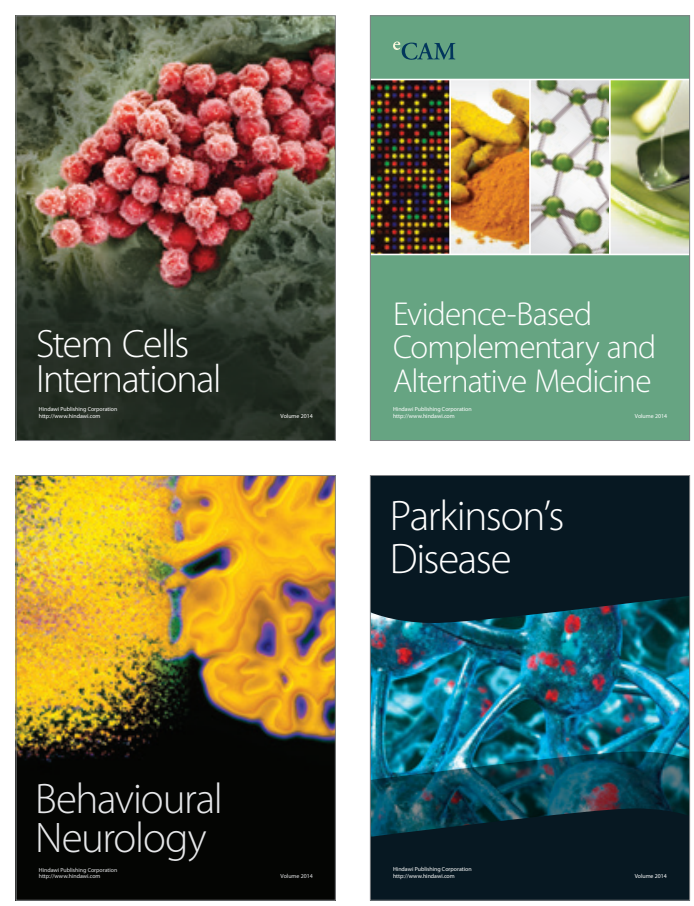

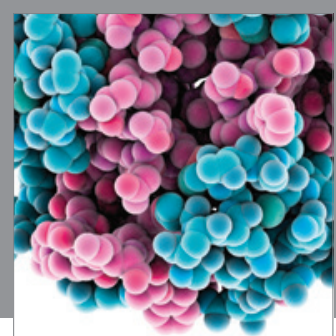

Journal of
Diabetes Research

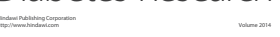

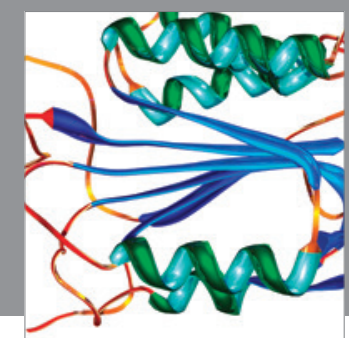

Disease Markers
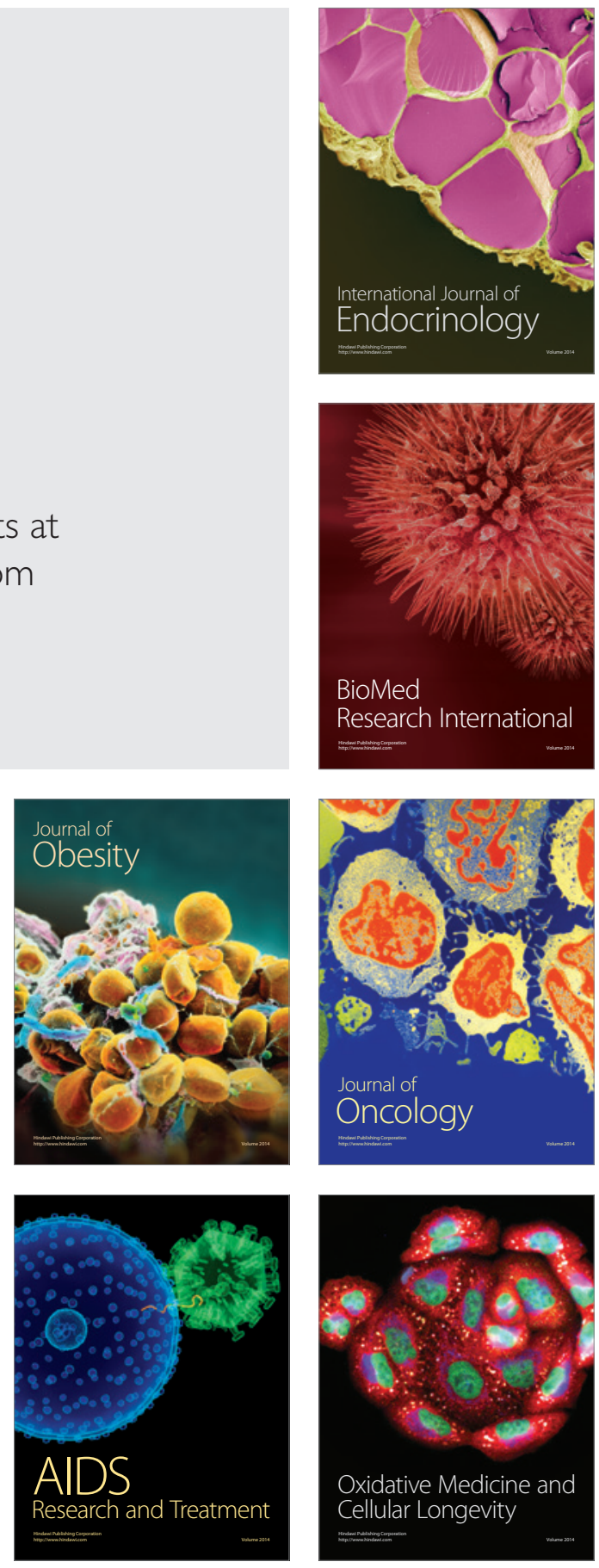